\title{
Effect of silkworm (Bombyx mori) pupae on the growth and maturation of rainbow shark Epalzeorhynchos frenatum (Fowler, 1934) under captive rearing
}

\author{
P. KARTHICK RAJA ${ }^{1}$, S. AANAND ${ }^{2}$, J. STEPHEN SAMPATHKUMAR ${ }^{3}$ AND P. PADMAVATHY ${ }^{1}$ \\ ${ }^{1}$ Fisheries College and Research Institute, Tamil Nadu Dr. J. Jayalalitha Fisheries University, Thoothukudi - 628008 \\ Tamil Nadu, India \\ ${ }^{2}$ Erode Bhavanisagar Centre for Sustainable Aquaculture, Tamil Nadu Dr. J. Jayalalitha Fisheries University \\ Bhavanisagar, Erode - 638 451, Tamil Nadu, India \\ ${ }^{3}$ Directorate of Sustainable Aquaculture, Tamil Nadu Dr. J. Jayalalitha Fisheries University, Thanjavur - 614904 \\ Tamil Nadu, India \\ e-mail: karthickkathir2212@gmail.com
}

\begin{abstract}
The aim of this study was to determine the impact of replacing fishmeal with silkworm pupae (Bombyx mori) meal in the diet of rainbow shark Epalzeorhynchos frenatum (Fowler, 1934), on growth and maturation. Four isonitrogenous and isocalorific experimental diets (35\% CP) were prepared using silkworm pupae (SWP) replacing fish meal at three different levels viz., $30 \%(\mathrm{~T} 1), 40 \%$ (T2) and 50\% (T3) and diet with only fish meal served as control (C). The experimental trail was conducted in hapas, in duplicates, installed in an earthen pond. The fish (average weight - $1.4 \mathrm{~g}$ and total length $-5.24 \mathrm{~cm}$ ) were stocked @ 10 nos. per hapa. During the experimental period, water quality parameters were monitored routinely. The experimental diets T1, T2 and T3 performed significantly better than diet C (control) in terms of growth performance. Among the four diets, T1 showed significantly higher weight gain $(5.18 \pm 0.28 \mathrm{~g})$, specific growth rate, SGR $\left(2.54 \pm 0.07 \%\right.$ day $\left.^{-1}\right)$, protein efficienvy ratio, PER $(1.50 \pm 0.04)$ and feed conversion ratio, FCR $(1.91 \pm 0.06)$ compared to other treatment groups. Among all the diets, highest gonadosomatic index, GSI (14.90\%) was obtained in fish fed diet T1. At the end of the experiment, all the experimental diets fed fishes showed similar stages of maturity i.e., late vitellogenic stage. Overall, the results of the present study conclude that SWP can be used as a low-cost animal protein to replace fish meal upto $30 \%$ in the diet.
\end{abstract}

Keywords: Fish meal replacement, Low cost ingredient, Maturational diet, Ornamental fish diet, Rainbow shark, Silkworm pupae

\section{Introduction}

Fishmeal (FM) is one of the major feed ingredient used in the preparation of fish feed due its balanced amino acid composition, high digestibility and palatability, which enhances the uptake, digestion and absorption of nutrients in fish (Miles and Chapman, 2006). However, the steady decline in catches of wild fish and the increased demand for quality aquaculture feed resulted in a rapid decrease in the availability of fishmeal (FAO, 2014). Shortage in fish meal results in high price of fish feed (Rana, et al., 2009; Ayoola, 2010), which demands low cost alternative feed ingredients for sustainable development of aquaculture.

This silkworm (Bombyx mori) pupae (SWP), derived from reeled silk, is used as a protein source in animal feed, due to its high nutritional value and low cost, as well as it is an important fish feed ingredient in the Indo-Pacific region (Hora and Pillay, 1962). Dried SWP is a valuable source of protein (50-71\% dry matter DM) and lipid (30\%) (Wei and Liu, 2001). The contents of essential amino acids and protein in silkworm pupae are comparable to fish meal. The fatty acid compositions of lipids of SWP are oleic, palmitic, palmitoleic, stearic, linoleic ( $24.6 \%$ of total lipid), lauric, myristic, linolenic (14\% of total lipid) and arachidic acids. The unsaturated fatty acids constitute one-third of the total acids. This SWP has been successfully used as a FM replacement for fish such as catla (Jayaram and Shetty, 1980), rohu (Jayaram and Shetty, 1980; Begun et al., 1994), common carp (Chakraborty et al., 1973; Nandeesha et al., 1990, 2000), mirror carp (Rahman et al., 1996) and jian carp (Ji et al., 2015). Fingerlings of the ornamental fish, silver barb performed better than control, when fed with a diet replacing fish meal with $38 \%$ silkworm pupae (Mahata et al., 1994).

Rainbow shark Epalzeorhynchos frenatum (Fowler, 1934) belonging to the Cyprinidae family, has good demand in ornamental aquarium fish trade. The huge market demand for this fish has led to large scale breeding 
of the species in captivity (Axelrod and William, 1995). However, production of rainbow shark seed throughout the year does not happen as mature broodstock are not available throughout the year. Nutritionally balanced diet is essential for ornamental fish to attain maturation in confined waters. SWP has been observed to be a good and cheap source of protein for ornamental fish (Stahlin, 1957). On the other side, study on SWP inclusion in ornamental fish diets in India is scanty. To our knowledge, there is no research report on replacement of FM with SWP for growth and maturation in the diet of rainbow shark. Hence, the present investigation was carried out to assess the effect of silkworm pupae on the growth and maturation of rainbow shark, E. frenatum under captivity.

\section{Materials and methods}

\section{Experimental fish}

Experimental fish (E. frenatum), in the weight range of 1.3 to $1.5 \mathrm{~g}$ were collected from M/s Udhayam Fish Farm, Tirunelveli, Tamil Nadu, India. The fish were transported in oxygenated HDPE bags to the study location at the Centre for Sustainable Aquaculture, Bhavanisagar, Tamil $\mathrm{Nadu}$, India. They were acclimatised for 2 weeks in hapa installed in an earthen pond. During acclimatisation, the fish were fed a control feed prepared for the experiment ( $35 \%$ protein), at the rate of $5 \%$ body weight. Water quality parameters were maintained at optimal level during the acclimatisation period.

\section{Experimental design}

Experiment was conducted in hapas installed in an earthen pond, for a period of 60 days. The experimental setup comprised of 3 sets of treatments and 1 set of control, in duplicates. Rainbow shark fingerlings (average weight of $1.44 \pm 0.22 \mathrm{~g}$ and total length $5.24 \pm 0.33 \mathrm{~cm}$ ) were stocked at a density of 10 nos. per hapa. Fish were fed twice a day ( $09.30 \mathrm{hrs}$ and $16.00 \mathrm{hrs})$ at the rate of 5\% of their body weight.

\section{Preparation of silkworm pupae meal}

Dried silkworm pupae were procured from a private silk reeling industry located in Erode, Tamil Nadu, India. Prior to feed preparation, the outer layer of silk thread (cocoon) was removed from pupae. The cleaned pupae were completely sun dried for two days and ground into powder form which was then stored in an airtight plastic container. The proximate composition of non-deoiled silkworm pupae meal was analysed following standard methods (AOAC, 1995).

\section{Preparation of experimental diets}

Four experimental diets (iso-nitrogenous and iso-caloric pelleted diets), having $35 \%$ crude protein were prepared from different combinations of selected feed ingredients (Table 1). Diet with only fishmeal served as control (C) and silkworm pupae (non-deoiled) was used to replace fish meal at 30\% (T1), 40\% (T2) and 50\% (T3) levels. Weighed amounts of the respective ingredients were mixed with sufficient quantity of water to form a dough which was cooked in a pressure cooker for $30 \mathrm{~min}$. The dough was then cooled, mixed with the vitaminmineral mixture and extruded through a pelletiser. The pellets were subsequently dried at about $60^{\circ} \mathrm{C}$ until the moisture content was reduced to less than $10 \%$ (Nandeesha et al., 2000). Proximate composition of the experimental diets and control diets were analysed following standard methods (AOAC, 1995) (Table 2).

\section{Sampling and water quality analysis}

After stocking of experimental fish, the hapas were cleaned once in a week, to ensure proper water circulation, as well as to get rid of algae and other matter clogging the net. During the experimental period,

Table 1. Ingredient composition of formulated experimental diets ( $\%$ of diet)

\begin{tabular}{lllll}
\hline \multirow{2}{*}{ Ingredients } & Control & \multicolumn{3}{c}{ Non-deoiled SWP } \\
\cline { 2 - 5 } & $\mathrm{C}$ & $30 \%$ & $\mathrm{~T} 2$ & $\mathrm{~T} 3$ \\
\hline Fish meal & 30 & 21 & 18 & $50 \%$ \\
SWP & - & 9 & 12 & 15 \\
Groundnut oil cake & 29 & 31 & 32 & 33 \\
Corn flour & 29 & 27 & 26 & 25 \\
Cassava starch & 6 & 6 & 6 & 6 \\
Salt & 1 & 1 & 1 & 1 \\
Vitamin premix & 0.5 & 0.5 & 0.5 & 0.5 \\
Mineral premix & 0.5 & 0.5 & 0.5 & 1 \\
Yeast & 1 & 1 & 1 & 0.7 \\
Vitamin E & 0.7 & 0.7 & 0.7 & 2.3 \\
Vegetable oil & 2.3 & 2.3 & 2.3 & \\
\hline
\end{tabular}


Table 2. Proximate composition of silkworm pupae meal (SWP) and experimental diets

\begin{tabular}{lllllll}
\hline Diet & $\begin{array}{l}\text { Crude protein } \\
(\%)\end{array}$ & $\begin{array}{l}\text { Ether extract } \\
(\%)\end{array}$ & $\begin{array}{l}\text { Crude fibre } \\
(\%)\end{array}$ & $\begin{array}{l}\text { Total ash } \\
(\%)\end{array}$ & $\begin{array}{l}\text { Moisture } \\
(\%)\end{array}$ & $\begin{array}{l}\text { Gross energy } \\
\left(\mathrm{Kcal}_{\mathrm{kg}} \mathbf{H}^{-1}\right)\end{array}$ \\
\hline SWP meal (Non-deoiled) & 55.63 & 27.41 & - & - & 7.68 & - \\
Fish meal & 68.21 & 9.1 & 1.1 & 15.1 & 10.6 & 5062.56 \\
C & 36.27 & 6.43 & 3.22 & 8.06 & 8.81 & 4474 \\
T1 & 34.65 & 9.07 & 3.58 & 7.10 & 7.73 & 4456 \\
T2 & 34.77 & 9.54 & 4.02 & 7.03 & 8.05 & 4457 \\
T3 & 35.78 & 11.57 & 4.07 & 6.46 & 7.66 & 4556 \\
\hline
\end{tabular}

water quality parameters were analysed daily following standard procedures (APHA, 2005). Sampling for growth performance analysis was conducted fortnightly and bio-growth parameters were calculated using the following formulae:

Mean weight gain $(g)=$ Mean final weight $(g)$ - Mean initial weight $(\mathrm{g})$

Specific growth rate, SGR $\left(\%\right.$ day $\left.^{-1}\right)=\ln$ final Weight $-\ln$ initial Weight / Experimental duration in days X 100

Survival rate, SR $(\%)=$ Final numbers of fish obtained/ Initial numbers of fish stocked X 100

Feed conversion ratio $(\mathrm{FCR})=$ Total dry feed fed $(\mathrm{g}) /$ Total wet weight gain $(\mathrm{g})$

Feed efficiency $(\mathrm{FE})=$ Body weight gain (wet weight) / Feed given (dry weight)

Protein efficiency ratio $($ PER $)=$ Total wet weight gain $/$ Dry weight of protein fed.

Gonadal maturation study

For studying the gonadal maturation and ovary development, one fish ( $\mathrm{n}=2$ per treatment) from each hapa was taken out and sacrificed. The gonads were observed on the $45^{\text {th }}$ and $60^{\text {th }}$ days of the experiment. The experimental fish were dissected and gonads were taken out with the help of forceps and weighed. Gonadosomatic index (GSI) was calculated using the formula: GSI $=$ Weight of gonad (g) / Body weight of fish $(\mathrm{g}) \times 100$.

The gonad samples collected for histological examination were immediately fixed in $10 \%$ neutral buffered formalin. The fixed tissue samples were processed as per Humason (1972) and sections of $5 \mu \mathrm{m}$ thickness were cut using a microtome (Thermo scientific ${ }^{\mathrm{TM}} 325$ ). Histological sections were then observed under a compound microscope (Nikon Eclipse E200) to assess the developmental stages of gonads.

\section{Statistical analysis}

The results are presented as mean \pm standard deviation. Data were analysed by one-way ANOVA using the statistical software SPSS 16.0 for windows (SPSS Inc., Chicago, USA). Duncan's multiple range test was used for post-hoc comparison of mean values. The significance level was set at $\mathrm{p}<0.05$.

\section{Results}

Water quality parameters

The range of water quality parameters such as temperature, dissolved oxygen, $\mathrm{pH}$, ammonia- $\mathrm{N}$, nitrite- $\mathrm{N}$ and phosphate-P were within the optimal range for rearing of rainbow shark (Table 3 ).

\section{Growth performance}

Results of the present study showed significant differences $(p<0.05)$ in growth performance of rainbow shark fed diets with FM replaced by non-deoiled SWP at 30 (T1), 40 (T2) and 50\% (T3) and the control (C) diet (Fig. 1).No mortality was observed during the experimental period. The experimental diets $\mathrm{T} 1, \mathrm{~T} 2$ and $\mathrm{T} 3$ performed significantly $(p<0.05)$ better than diet $C$ (control) in terms of growth performance and feed utilisation by the fishes (Table 4$)$. Significantly higher $(p<0.05)$ mean body weight gain $(5.18 \pm 0.28 \mathrm{~g})$ was obtained in fish fed diet $\mathrm{T} 1$ followed by $\mathrm{T} 2(3.80 \pm 0.42 \mathrm{~g})$, whereas the lowest $(p<0.05)$ mean body weight gain $(2.76 \pm 0.02 \mathrm{~g})$ was obtained in fish fed on control (C) diet (Table 4$)$. The highest $(\mathrm{p}<0.05)$ percentage weight gain $(359 \%)$ was obtained in fish fed diet T1 followed by T2 $(264 \%)$, whereas the lowest $(\mathrm{p}<0.05)$ percentage weight gain $(192 \%)$ was obtained in fish fed on control diet (Table 4). SGR of various diets ranged from 1.79 to $2.54 \%$ day $^{-1}$ (Table 4) and showed significant difference $(\mathrm{p}<0.05)$. The highest SGR was observed in fish fed diet $\mathrm{T} 1$ followed by $\mathrm{T} 2$ and the lowest SGR obtained in fish fed control diet $(\mathrm{p}<0.05)$. FCR in this study ranged from 1.91 to 2.8 (Table 4 ) with significantly lowest $(\mathrm{p}<0.05)$ value in fish fed diet T1 $(1.91 \pm 0.06)$, followed by T2 $(2.38 \pm 0.25)$

Table 3. Water quality parameters (Mean $\pm \mathrm{SD}$ ) recorded during the experimental period

\begin{tabular}{ll}
\hline Parameters & Mean \pm SD \\
\hline Temperature $\left({ }^{\circ} \mathrm{C}\right)$ & $27.5 \pm 0.75$ \\
Dissolved oxygen $(\mathrm{ppm})$ & $4.75 \pm 0.30$ \\
$\mathrm{pH}$ & $8.1 \pm 0.17$ \\
Ammonia-N (ppm) & $0.07 \pm 0.04$ \\
Nitrite-N (ppm) & $0.55 \pm 0.14$ \\
Phosphate-P (ppm) & $0.22 \pm 0.08$ \\
\hline
\end{tabular}


Table 4. Growth parameters of rainbow shark fed with diets containing non-deoiled SWP at different levels of FM replacement

\begin{tabular}{|c|c|c|c|c|c|c|c|c|c|c|c|}
\hline Diet & $\begin{array}{l}\text { Mean initial } \\
\text { weight }(\mathrm{g})\end{array}$ & $\begin{array}{l}\text { Mean final } \\
\text { weight (g) }\end{array}$ & $\begin{array}{l}\text { Mean } \\
\text { weight } \\
\text { gain }(\mathrm{g})\end{array}$ & $\begin{array}{l}\text { Mean initial } \\
\text { length }(\mathrm{cm})\end{array}$ & $\begin{array}{l}\text { Mean final } \\
\text { length } \\
(\mathrm{cm})\end{array}$ & $\begin{array}{l}\text { Mean } \\
\text { length } \\
\text { gain }(\mathrm{cm})\end{array}$ & $\begin{array}{l}\text { Percentage } \\
\text { weight Gain } \\
\text { (PWG) }\end{array}$ & SGR & FCR & FER & PER \\
\hline Control & \multirow{4}{*}{$1.44 \pm 0.22$} & $4.20 \pm 0.02^{\mathrm{c}}$ & $2.76 \pm 0.02^{\mathrm{c}}$ & \multirow{4}{*}{$5.24 \pm 0.33$} & $7.79 \pm 0.08^{b}$ & $2.55 \pm 0.08^{b}$ & $192.01 \pm 1.47^{\mathrm{c}}$ & $1.79 \pm 0.01^{\mathrm{c}}$ & $2.85 \pm 0.02^{\mathrm{a}}$ & $0.35 \pm 0.00^{\mathrm{b}}$ & $0.96^{b}$ \\
\hline $\mathrm{T} 1$ & & $6.62 \pm 0.28^{\mathrm{a}}$ & $5.18 \pm 0.28^{\mathrm{a}}$ & & $8.92 \pm 0.23^{\mathrm{a}}$ & $3.68 \pm 0.23^{\mathrm{a}}$ & $359.38 \pm 19.15^{\mathrm{a}}$ & $2.54 \pm 0.07^{\mathrm{a}}$ & $1.91 \pm 0.06^{\mathrm{b}}$ & $0.52 \pm 0.02^{\mathrm{a}}$ & $1.50 \pm 0.04^{\mathrm{a}}$ \\
\hline $\mathrm{T} 2$ & & $5.25 \pm 0.42^{\mathrm{b}}$ & $3.80 \pm 0.42^{\mathrm{b}}$ & & $8.2 \pm 0.09^{\mathrm{b}}$ & $2.97 \pm 0.09^{\mathrm{b}}$ & $264.24 \pm 28.97^{\mathrm{b}}$ & $2.15 \pm 0.13^{\mathrm{b}}$ & $2.38 \pm 0.25^{\mathrm{ab}}$ & $0.42 \pm 0.04^{\mathrm{b}}$ & $1.21 \pm 0.12^{\mathrm{b}}$ \\
\hline $\mathrm{T} 3$ & & $4.92 \pm 0.38^{\mathrm{bc}}$ & $3.48 \pm 0.38^{\mathrm{bc}}$ & & $8.07 \pm 0.19^{\mathrm{b}}$ & $2.83 \pm 0.19^{\mathrm{b}}$ & $241.67 \pm 26.52^{\mathrm{bc}}$ & $2.05 \pm 0.13^{\mathrm{bc}}$ & $2.64 \pm 0.27^{\mathrm{b}}$ & $0.38 \pm 0.04^{\mathrm{b}}$ & $1.06 \pm 0.10^{\mathrm{b}}$ \\
\hline \multicolumn{12}{|c|}{ One way ANOVA $(p<0.05)$} \\
\hline Diet & - & 0.007 & 0.007 & - & 0.009 & 0.009 & & 0.007 & 0.029 & 0.018 & 0.013 \\
\hline
\end{tabular}

Values are presented as mean $\pm \mathrm{SD}$

Values in the same column with different superscripts differ significantly $(\mathrm{p}<0.05)$ for each parameter.

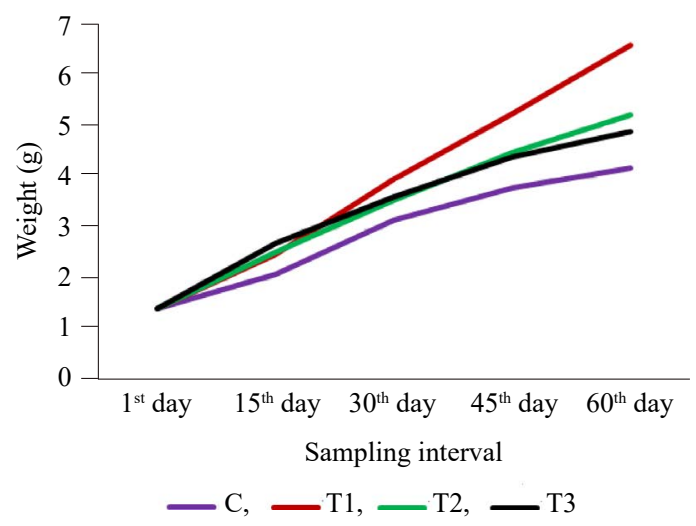

Fig. 1. Growth performance of rainbow shark fed with diets containing non-deoiled and deoiled SWP replacing FM at 30,40 and $50 \%$

and highest value in control diet (2.85). Better PER value was recorded in fish fed diet T1 $(1.50 \pm 0.04)$, followed by T2 (1.21 \pm 0.12$)$ and the least PER was recorded in diet $\mathrm{C}(0.96)$ which is significantly lower $(\mathrm{p}<0.05)$ than other treatments (Table 4$)$.

\section{Ovary development and gonadal maturation}

The gonadosomatic indices (GSI) recorded ranged from 11.74 to $14.90 \%$ observed on $60^{\text {th }}$ day (Table 5). As it is evident, among the treatments, T1 recorded the highest GSI (14.90\%) followed by T2 (13.01\%). Control fish showed the lowest GSI $(11.74 \%)$ that was significantly lower $(\mathrm{p}<0.05)$ than that of fishes from the treatment groups.
Histological sections of ovary of fishes sampled in the beginning of the experiment showed undeveloped ovary, with numerous primary oocytes, mostly in the perinucleolar phase. Gonad sections of fishes fed control and SWP incorporated experimental diets showed more of mid-vitellogenic ova and few late-vitellogenic ova on the $45^{\text {th }}$ day of the experiment (Fig. 2). On the $60^{\text {th }}$ day of experiment (Fig. 3), control as well as the experimental diets showed similar stages of maturity i.e., late vitellogenic stage characterised by clear ova with distinct nucleus with some of the eggs in maturing phase.

\section{Discussion}

Among the three SWP incorporated diets, 30\% inclusion of non-deoiled SWP led to highest weight gain, SGR, PER, FER and better FCR. This outcome is in line with the findings of Mahata et al. (1994), who reported that silver barb (Barbonymus gonionotus) fingerlings performed better than fish meal-based diet, when fed a diet replacing fish meal with $38 \%$ SWP. Similar studies with catla (Jayaram and Shetty, 1980; Nandheesa et al., 1989; Hasan, 1991) and common carp (Jayaram and Shetty, 1980; Nandheesa et al., 1990) revealed 30\% fishmeal replacement with SWP, exhibited better growth performances and feed efficiencies.

Results of the present study showed that the highest SGR value was obtained with diet T1 having 30\% SWP and the range of SGR recorded in the present study was 1.80 to $2.54 \%$ day $^{-1}$. Begum et al. (1994) reported that

Table 5. Observations on the weight of the gonads of E. frenatum fed with a diet having fish meal replaced with non-deoiled SWP at 30,40 and $50 \%$ respectively on the $60^{\text {th }}$ day

\begin{tabular}{|c|c|c|c|c|c|c|c|}
\hline \multirow{2}{*}{ Experimental diets } & \multicolumn{2}{|c|}{ Weight of fish (g) } & \multicolumn{2}{|c|}{ Weight of gonad (g) } & \multicolumn{2}{|c|}{ GSI (\%) } & \multirow{2}{*}{ Mean \pm SD GSI $(\%)$} \\
\hline & Replicate1 & Replicate2 & Replicate1 & Replicate2 & Replicate1 & Replicate2 & \\
\hline Control (C) & 6.8 & 6.9 & 0.75 & 0.86 & 11.02 & 12.46 & $11.74 \pm 1.01^{\mathrm{c}}$ \\
\hline T1(30\% non-deoiled SWP) & 8.5 & 8.20 & 1.28 & 1.21 & 15.05 & 14.75 & $14.90 \pm 0.21^{\mathrm{a}}$ \\
\hline $\mathrm{T} 2-(40 \%$ non-deoiled SWP $)$ & 8.0 & 8.2 & 1.01 & 1.10 & 12.62 & 13.41 & $13.01 \pm 0.55^{\mathrm{b}}$ \\
\hline T3 (50\% non-deoiled SWP) & 8.24 & 7.95 & 0.99 & 0.92 & 12.01 & 11.57 & $11.79 \pm 0.31^{\mathrm{bc}}$ \\
\hline
\end{tabular}

Values are presented as mean $\pm \mathrm{SD}$

Values in the same column with different superscripts differ significantly $(\mathrm{p}<0.05)$ for each parameter 


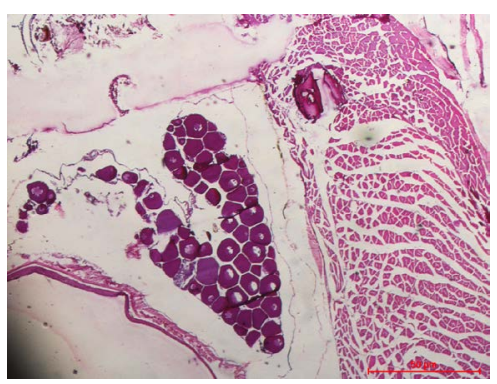

(a)

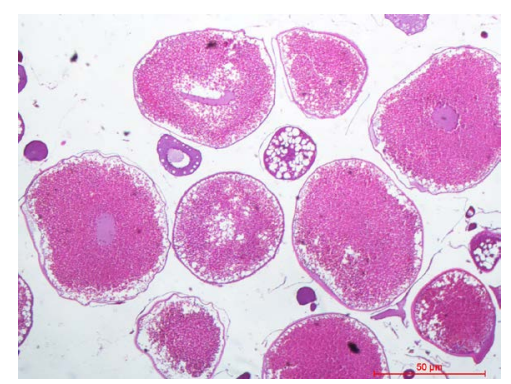

(b)

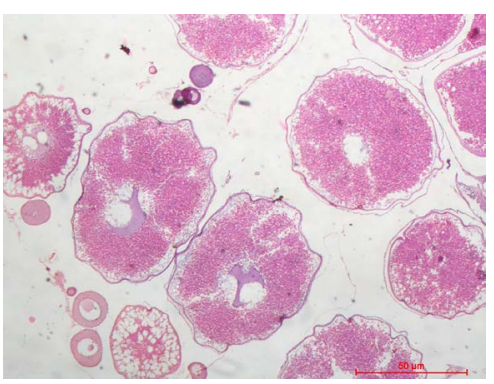

(c)

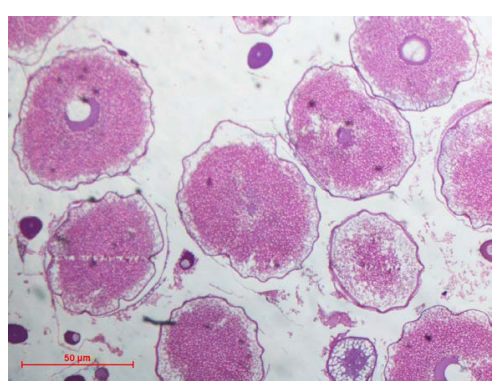

(d)

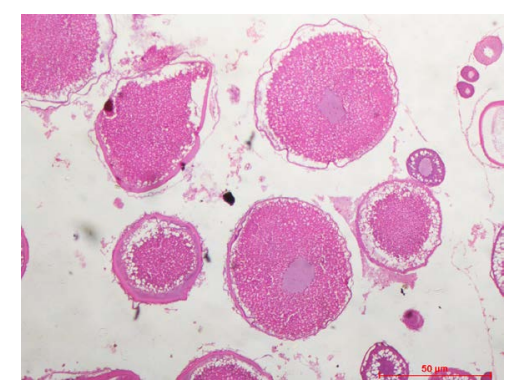

(e)

Fig. 2. Histological sections of rainbow shark ovary. (a) Perinucleolar phase observed at the beginning of the experiment; Mid-vitellogenic stage observed in (b) Control; (c) T1, (d) T2 and (e) T3 on the $45^{\text {th }}$ day

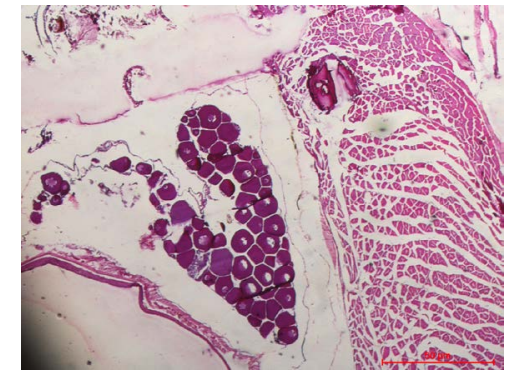

(a)

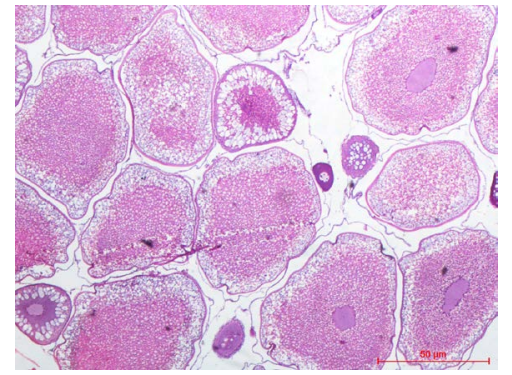

(b)

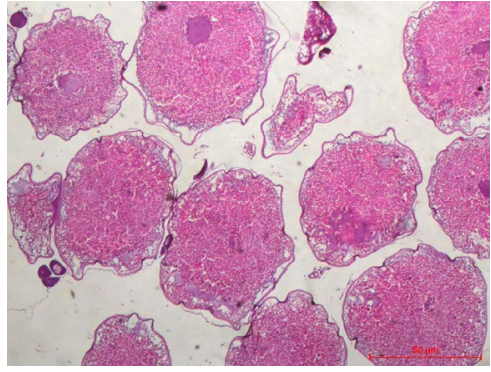

(c)

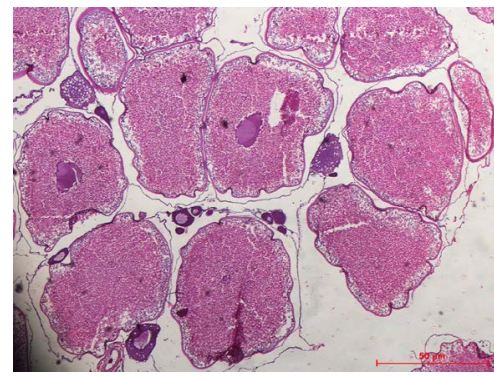

(d)

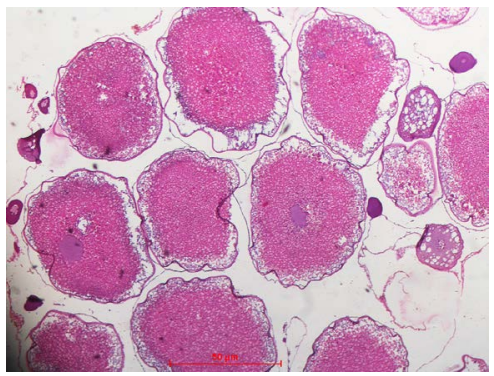

(e)

Fig. 3. Histological sections of rainbow shark ovary. (a) Perinucleolar phase observed at the beginning of the experiment. Late-vitellogenic stage observed in (b) Control; (c) T1; (d) T2 and (e) T3 on the $60^{\text {th }}$ day

better SGR $\left(1.64 \%\right.$ day $\left.^{-1}\right)$ was observed in rohu when fed 50\% silkworm pupae diet. Habib et al. (1994) found that Clarias batrachus fed SWP included diets had higher SGR values ( 2.06 to $2.12 \%$ day $^{-1}$ ) compared to fish meal, blood worm and poultry byproduct meal supplemented diets (1.94 to $1.99 \%$ day $\left.^{-1}\right)$. Further it was observed that, SWP can be a cheap and effective alternative protein source than poultry byproduct meal and blood meal in the diet of C. batrachus. Further, Salem et al. (2008) in Nile tilapia (1.2 to $1.425 \mathrm{day}^{-1}$ ) as well as Ji et al. (2015) in jian 
carp (2.10 to $2.32 \%$ day $^{-1}$ ) also reported similar range of SGR values when fed diets containing different levels of fishmeal replaced with silkworm pupae.

FCR value is used as an important growth determining factor, as feed constitutes the largest operational cost in aquaculture system (Amin et al., 2005). The FCRvalues observed in the present study ranged from 1.91 to 2.8 . However, the values were similar to the FCR values reported by Habib et al. (2001) who documented FCR values of 1.95 to 2.70 in C. batrachus fed with silkworm pupae-based diet. Nandheesa et al. (1988) found that catla-rohu hybrid fed with diets containing SWP had better FCR (2.07 to 2.48). Nandheesa et al. (1990) in common carp fry, Jayaram and Shetty (1980) in L. rohita fingerlings and Oso and Iwalaye (2014) in Clarias gariepinus juveniles also found similar results when fed diets containing various levels of SWP.

Steffens (1981) reported that PER values can be used to evaluate the quality of protein in the diet, those with high PER values, indicate good quality of protein. PER values recorded in the present study were in the range of 1.00 to 1.50 . Results showed that fish fed $30 \%$ SWP diet had higher PER value compared to other diets. Begum et al. (1994) reported PER value of 1.35 to 1.50 in rohu when fed diet containing different levels of silkworm pupae. Habib et al. (2001) reported PER of 0.95 to 1.25 for diets containing different levels of non-deoiled SWP in C. batrachus.

In our study, 40 and $50 \%$ replacement of fishmeal with SWP showed significantly better growth performance compared to the control diet. Earlier studies with rohu (Begun et al., 1994) and common carp (Nandheesa et al., 2000) have shown the best growth performance upto $50 \%$ FM replaced with silkworm pupae. The present study also showed that weight gain in fishes fed diets with 40 and $50 \%$ replacement of fishmeal with SWP was comparatively less than fishes fed $30 \%$ SWP diet. Increase in the dietary SWP level resulted in significant decrease in growth rate. Similar findings were reported by Ji et al. (2015) in jian carp and Salem et al. (2008) in Nile tilapia. This may primarily be due to high levels of chitin in SWP (5-15\%) which is poorly digested by fish (Cummins et al., 2017). Further studies in fish, showed that increased substitution or replacement of FM by insect meal simultaneously increase the chitin level and affected the digestibility of proteins (Longvah et al., 2011) and lipids (Kroeckel et al., 2012). Replacement of FM by 30\% non-deoiled SWP showed higher protein digestibility in catla (Umalatha et al., 2018), common carp (Jayaram and Shetty, 1980; Nandheesa et al., 1990; Gangadhar et al., 2017) and Labeo firmbriatus (Gangadhar et al., 2017), compared to fishes fed control diet.
In the present study, ovary development on the $60^{\text {th }}$ day of the experiment, in the control and treatments showed similar stage of maturity i.e., late vitellogenic stage. Resutls of the resent study clearly indicated that replacement of fishmeal by silkworm pupae meal will not affect maturation of the fish. In short, all the experimental diets used in the experiment helped in development of ovary and maturation of ova.

From results of the present study, it could be concluded that SWP can be used to replace FM in the diets of rainbow shark. However, replacement levels of $30 \%$ was found to be more efficient. Increasing levels of incorporation of SWP in the diet leads to reduced growth and increased FCR. Further, SWP is cheaper than FM and it would definitely provide a cheap alternative protein source to improve the yield for farmers.

\section{Acknowledgements}

The study was carried out at Erode Bhavanisagar Centre for Sustainable Aquaculture, Bhavanisagar, Erode. The authors sincerely thank TNJFU, Nagapattinam, Tamil Nadu, India for the grants and facilities offered. We also thank the Director, Directorate for Sustainable Aquaculture, Thanjavur, for providing all facilities to conduct the feeding trial.

\section{References}

Amin, A. K. M. R., Bapary, M. A. J., Islam Shajahan, M. and Hossain, M. A. R. 2005. The impacts of compensatory growth on food intake, growth rate and efficiency of feed utilisation in Thai pangas (Pangasius hypophthalmus). Pak. J. Biol. Sci., 8(5): 766-770. DOI: 10.3923/pjbs. 2005.766.770.

AOAC 1995. Official methods of analysis, $13^{\text {th }}$ edn. Association of Official Analytical Chemists, Washington D. C., USA.

APHA 2005. Standard methods for the examination of water and wastewater, $22^{\text {nd }}$ edn. American Public Health Association, Washington, D. C., USA, 541 pp.

Axelrod, H. R. and William, V. 1995. Encyclopedia of tropical fish. TFH Publications, Neptune, New Jersey, USA, 631 pp.

Ayoola, A. A. 2010. Replacement of fishmeal with alternative protein source in aquaculture diets. M. Sc. Thesis, Faculty of North Carolina State University, North Carolina, USA.

Begum, N. N., Chakraborty, S. C., Zaher, M., Abdul, M. M. and Gupta, M. V. 1994. Replacement of fishmeal by low-cost animal protein as a quality fish feed ingredient for Indian major carp, Labeo rohita, fingerlings. J. Sci. Food Agric., 64(2): 191-197. https://doi.org/10.1002/jsfa.2740640207.

Chakrabarthy, R. D., Sen, P. R. and Kowtal, G. V. 1973. Observations on the relative usefulness of different feeds for carp spawn and fry. J. Inland Fish. Soc. India, 5: 182-188. 
Cummins Jr, V. C., Rawles, S. D., Thompson, K. R., Velasquez, A., Kobayashi, Y., Hager, J. and Webster, C. D. 2017. Evaluation of black soldier fly (Hermetia illucens) larvae meal as partial or total replacement of marine fish meal in practical diets for Pacific white shrimp (Litopenaeus vannamei). Aquaculture, 473: 337-344. https://doi.org/10. 1016/j.aquaculture.2017.02.022.

FAO 2014. The state of world fisheries and aquaculture. Food and Agriculture Organisation, Rome, Italy, $230 \mathrm{pp}$.

Gangadhar, B., Umalatha, H., Ganesh, H., Saurabh, S. and Sridhar, N. 2017. Digestibility of dry matter and nutrients from three ingredients by the carps, Labeo fimbriatus (Bloch, 1795) and Cyprinus carpio Linnaeus, 1758 with a note on digestive enzyme activity. Indian J. Fish., 64(3): 75-84. DOI: 10.21077/ijf.2017.64.3.69091-11.

Habib, M. A. B., Hasan, M. R., Akand, A. M. and Siddiqua, A. 1994. Evaluation of silkworm pupae meal as a dietary protein source for Clarias batrachus fingerlings. Aquaculture, 124(1-4): p. 62.

Habib, M. A. B., Ullah, M. S., Hasan, M. R. and Akand, A. M. 2001. Use of silkworm pupae as partial replacement of fish meal in the diets with rotifer as feed additive of Asian catfish, Clarias batrachus fry. Bangladesh J. Fish., 24(1-2): 133-141.

Hasan, M. R. 1991. Studies on the use of poultry offal and silk worm pupae as dietary protein sources for Indian major carp, Catla (Hamilton) [Bangladesh]. Proceedings of the Workshop on Bangladesh Agricultural University Research Progress, Part B: Livestock, Fisheries, Agricultural Engineering and Socio-economics. Bangladesh Agricultural University, Mymensingh, Bangladesh, p. 415-442.

Hora, S. L. and Pillay, P. V. R. 1962. Handbook of fish culture in the Indo-pacific region. FAO Fisheries Technical Paper, 14. Food and Agriculture Organisation, Rome, Italy, 203 pp.

Jayaram, M. C. and Shetty, H. P. C. 1980. Studies on the growth rates of catla, rohu and common carp fed on different formulated feeds. Mysore J. Agric. Sci., 14(4): 598-606.

Ji, H., Zhang, J. L., Huang, J. Q., Cheng, X. F. and Liu, C. 2015. Effect of replacement of dietary fish meal with silkworm pupae meal on growth performance, body composition, intestinal protease activity and health status in juvenile Jian carp (Cyprinus carpio var. jian). Aqua. Res., 46(5): 1209-1221. https://doi.org/10.1111/are.12276.

Kroeckel, S., Harjes, A. G., Roth, I., Katz, H., Wuertz, S., Susenbeth, A. and Schulz, C. 2012. When a turbot catches a fly: Evaluation of a pre-pupae meal of the black soldier fly (Hermetia illucens) as fish meal substitute - Growth performance and chitin degradation in juvenile turbot (Psetta maxima). Aquaculture, 364: 345-352. https://doi. org/10.1016/j.aquaculture.2012.08.041.

Longvah, T., Mangthya, K. and Ramulu, P. 2011. Nutrient composition and protein quality evaluation of eri silkworm (Samia ricinii) prepupae and pupae. Food Chem., 128(2): 400-403.
Mahata, S. C., Bhuiyan, A. K. M. A., Zaher, M., Hossain, M. A. and Hasan, M. R. 1994. Evaluation of silkworm pupae as dietary protein source for Thai sharpunti, Puntius gonionotus (Bleeker). J.Aquac. Tropics, 9(1): 77-85.

Miles, R. D. and Chapman, F. A. 2006. The benefits of fish meal in aquaculture diets. IFAS Extension, University of Florida, Florida, USA.

Nandeesha, M. C., Srikanth, G. K., Varghese, T. G., Keshavanath, P. and Shethy, H. P. C. 1988. Influence of silkworm pupae-based diets on growth organoleptic quality and biochemical composition of catla-rohu hybrid. In: Aquacultural Research in Asia: Management techniques and nutrition. Proceedings of the. Asian Seminar on Aquaculture, IFS, Malang, Indonesia, p. 211-220.

Nandeesha, M. C., Basavaraja, N., Keshavanath, P., Varghese, T. J., Sudhakara, N. S., Srikanth, G. K., Ray, A. K. and Ray, A. 1989. Formulation of pellets with sericulture wastes and their evaluation in carp culture. Indian J. Anim. Sci., 59(9): 1198-1205.

Nandeesha, M. C., Srikanth, G. K., Keshavanath, P., Varghese, T. J., Basavaraja, N. and Das, S. K. 1990. Effects of non-defatted silkworm-pupae in diets on the growth of common carp, Cyprinus carpio. Biological Wastes, 33(1): 17-23. https://doi.org/10.1016/0269-7483(90)90118-C.

Nandeesha, M. C., Gangadhara, B., Varghese, T. J. and Keshavanath, P. 2000. Growth response and flesh quality of common carp, Cyprinus carpio fed with high levels of nondefatted silkworm pupae. Asian Fish. Sci., 13(3): 235-242.

Oso, J. A. and Iwalaye, O. A. 2014. Growth performance and nutrient utilisation efficiency of Clarias gariepinus juveniles fed Bombyx mori (Mulberry silkworm) meal as a partial replacement for fishmeal. British J. Appl. Sci. Technol., 4(26): 3805-3812.

Rahman, M. A., Zaher, M., Mazid, M. A., Haque, M. Z. and Mahata, S. C. 1996. Replacement of costly fish meal by silkworm pupae in diet of mirror carp (Cyprinus carpio L.). Pak. J. Sci. Ind. Res., 39(1-4): 64-67.

Rana, K. J., Siriwardena, S. and Hasan, M. R. 2009. Impact of rising feed ingredient prices on aquafeeds and aquaculture production, No. 541. In:. Fisheries and aquaculture technical paper, 63. Food and Agriculture Organisation of the United Nations, Rome, Italy.

Salem, M. F., Khalafalla, M. M. E., Saad, I. A. I. and El-Hais, A. M. A. 2008. Replacement of fish meal by silkworm Bombyx mori pupae meal, in Nile tilapia, Oreochromis niloticus diets. Egyptian J. Nutr. Feeds, 11(3): 611-624.

Stahlin, A. 1957. Method book vol. 12: Assessment of feed. Neumann Verlag, Germany (In German).

Steffens, W. 1981. Protein utilization by rainbow trout (Salmo gairdneri) and carp (Cyprinus carpio): A brief review. Aquaculture, 23(1-4): 337-345. https://doi.org/10.1016/00 44-8486(81)90026-0. 
Umalatha, H., Gangadhar, B., Hegde, G. and Sridhar, N. 2018. Digestibility of three feed ingredients by Catla catla (Ham. 1822). Oceanogr. Fish. Open Access J., 5: 555-672.

Wei, M. and Liu, G. 2001. The research and exploitation of insect protein. Journal of Central-South Forestry College, 21(2): 86-90. 